\title{
"Everything is scorched by the burning sun": missionary perspectives and experiences of 19th- and early 20th-century droughts in semi-arid central Namibia
}

\author{
Stefan Grab and Tizian Zumthurm \\ Correspondence to: Stefan Grab (stefan.grab@wits.ac.za)
}

The copyright of individual parts of the supplement might differ from the CC BY 4.0 License. 
Droughts

\begin{tabular}{|c|c|c|c|c|c|c|c|c|c|c|c|}
\hline Reported consequences & $1850-1851$ & $1858-1860$ & $1865-1869$ & $1877-1879$ & $1881-1882$ & $\begin{array}{r}\text { Droughts } \\
1887-1890\end{array}$ & 1895-1896 & $1900-1903$ & $1907-1908$ & $1910-1911$ & 1912-1913 \\
\hline Hunger & $*$ & $*$ & $*$ & $*$ & $*$ & $*$ & $*$ & $*$ & $*$ & & $*$ \\
\hline Starvation/human deaths & $*$ & & $*$ & $*$ & & $*$ & $*$ & & & $*$ & \\
\hline Barren wasteland & & $*$ & & $*$ & $*$ & $*$ & & & & & $*$ \\
\hline Grasslands degraded / no grass & $*$ & $*$ & $*$ & $*$ & $*$ & $*$ & & $*$ & $*$ & & $*$ \\
\hline Trees/bushes bare & & $*$ & & $*$ & & & & & & & \\
\hline Trees died & & & & * & & & & & & $*$ & \\
\hline Crop failures/no crop yields & & $*$ & & $*$ & & & & $*$ & $*$ & $*$ & $*$ \\
\hline Lack of wild foods & & & & $*$ & $*$ & $*$ & & $*$ & & $*$ & \\
\hline Livestock deaths $^{1}$ & & $*$ & $*$ & $*$ & $*$ & $*$ & $*$ & $*$ & & $*$ & $*$ \\
\hline Wells dried up & & $*$ & & $*$ & & & $*$ & $*$ & $*$ & $*$ & $*$ \\
\hline Springs stopped flowing & & $*$ & $*$ & $*$ & & & & $*$ & $*$ & & \\
\hline Concominant phenomena and human responses & & & & & & & & & & & \\
\hline Population dispersal (vacated mission stations) ${ }^{2}$ & $*$ & $*$ & $*$ & $*$ & $*$ & $*$ & $*$ & $*$ & $*$ & $*$ & $*$ \\
\hline Low school attendance ${ }^{3}$ & * & & & * & & $*$ & & $*$ & $*$ & & \\
\hline Livestock thefts \& social tensions ${ }^{4}$ & & & $*$ & $*$ & $*$ & $*$ & $*$ & & & $*$ & \\
\hline Farms vacated & & & & & & & & $*$ & & & $*$ \\
\hline Closure of mission stations & & & & & & & & $*$ & & & \\
\hline Begging for food at stations & & & & $*$ & & $*$ & & $*$ & & & \\
\hline Prayers for rain & & & & $*$ & $*$ & & $*$ & & & $*$ & \\
\hline Indigenous rain making ${ }^{5}$ & & & $*$ & & & & & & & & \\
\hline Food aid from the Cape & & $*$ & & & & & & & & & \\
\hline Fund raising for food aid & & & & $*$ & & & & $*$ & & & \\
\hline Colonial/governmental support & & & & & & & $*$ & $*$ & & & \\
\hline Collapse of transport system & & & & $*$ & & & $*$ & & $*$ & $*$ & \\
\hline Search for deeper wells & & & $*$ & $*$ & & & & & & & \\
\hline Digging/construction of deeper wells & & & & $*$ & & & & $*$ & $*$ & $*$ & $*$ \\
\hline Construction of water reservoirs & & & & & & & & $*$ & & $*$ & \\
\hline
\end{tabular}

Notes
1. Livestock deaths during droughts between 1895 and 1913 are due to the combined impacts of the cattle plague (Rinderpest) and drought

1. Livestock deaths during droughts between 1895 and 1913 are due to the combined in

3. Low school attendance was at times due to the combined factors of drought and social tensions/war

4. Drought variably (directly or indirectly) caused social tensions and theft (i.e. as either a primary or secondary causative factor)

5. Indigenous rain making is only referred to during the 1865-69 drought in our documentary records - this does not imply that the practice was absent during other drought events 